\title{
Pemberdayaan Usaha Mikro Kecil dan Menengah Sektor Pangan dalam Meningkatkan Perekonomian Lokal Melalui Pendampingan Sertifikasi Halal di Kecamatan Tragah Bangkalan
}

\author{
Galuh Widitya Qomaro*, Hammam, dan Khoirun Nasik \\ Program Studi Hukum Bisnis Syariah, Universitas Trunojoyo Madura \\ E-mail: gwiditya@trunojoyo.ac.id \\ DOI: https://doi.org/10.21107/pangabdhi.v5i2.6116
}

\begin{abstract}
Artikel Diterima : 12 Agustus 2019/ Revisi : 7 September 2019/Terbit : 19 Oktober 2019
Abstrak

Perkembangan usaha mikro kecil dan menengah di Kabupaten Bangkalan terbilang mengalami pasang surut dari tahun ke tahun. Salah satu usaha mikro kecil dan menengah yang dimiliki Kabupaten Bangkalan sebagai penggerak perekonomian masyarakat khususnya di Kecamatan Tragah adalah di bidang produk makanan. Dalam upaya meningkatkan kemandirian dan kesadaran produk halal Tim Abdimas mengadakan serangkaian kegiatan pelatihan dan pendampingan pendaftaran sertifikat halal untuk menunjang daya jual dan komersialitas produk yang dihasilkan UMKM Kecamatan Tragah. Kegiatan dibagi menjadi 3 (tiga) tahap yaitu persiapan, pelaksanaan, dan evaluasi. Persiapan dilakukan melalui kegiatan focus group discussion sebagai bagian dari survey pendahuluan untuk menilai kondisi dan pemahaman halal masyarakat dan UMKM. Pelaksanaan dilakukan dengan: (1) pelatihan dalam beberapa tema produk halal menggunakan teknik presentasi (2) pengenalan dan praktek pengisian form pendaftaran sertifikat halal Cerol SS23000 melalui website LPPOM MUI (3) pendampingan pendaftaran sertifikasi halal online. Evaluasi kegiatan dilakukan untuk masing-masing tahap dengan mengumpulkan dan menyimpulkan data dari masing- masing tahapan kegiatan sehingga dapat menjadi landasan data untuk keberlanjutan kegiatan.
\end{abstract}

Kata kunci: sertifikasi halal, jaminan produk halal, UMKM, Tragah

\section{PENDAHULUAN}

Sebagai wilayah dengan mayoritas penduduk muslim dan dipandang kuat keislamannya, Madura diharapkan dapat menjadi contoh wilayah dalam penerapan hukum terutama dalam aspek yang bersentuhan langsung dengan kehidupan sehari- sehari. Misalnya ketentuan dalam hal makanan yang halal. Ketentuan ini wajib dijalankan oleh seluruh muslim dimanapun dia berada. Untuk menjalankan ketentuan tersebut, harus dapat dipastikan bahwa setiap makanan dan minuman yang beredar di tengahtengah masyarakat dapat diidentifikasi (dikenali) apakah halal sehingga dapat dikonsumsi ataukah haram sehingga harus ditinggalkan. Pemerintah selaku pengatur urusan masyarakat memiliki kewajiban untuk memastikan bahwa makanan yang beredar dapat dikenali halal atau haramnya.

Dalam hal ini Pemerintah memberikan wewenang kepada MUI melalui LPPOM (Lembaga Pengkajian Pangan Obat-obatan dan Kosmetika) untuk pengawasan dan pemeriksaan serta sertifikat produk halal yang kemudian dilanjutkan dengan disahkannya UU No. 33 tahun 2014 tentang Jaminan Produk Halal yang mana pemerintah akan mengambil alih dalam penerbitan sertifikat melalui badan penyelenggara jaminan produk halal yang berada di bawah naungan Kementerian Agama. Dengan diberlakukannya UU No. 33 tahun 2014, sertifikasi halal tidak lagi bersifat voluntery akan tetapi menjadi mandatory yang artinya setiap produk makanan dan minuman yang diperjualbelikan dan diedarkan ke masyarakat luas harus bersertifikasi halal. Dalam UU JPH pasal 67 dijelaskan kewajiban bersertifikasi bagi produk yang beredar dan diperdagangkan akan mulai berlaku terhitung lima tahun sejak UU JPH disahkan, artinya pada tahun 2019 ini pada bulan oktober semua produk yang diperjualbelikan dan diedarkan haruslah bersertifikasi halal, termasuk produk UMKM.

Dengan disahkannya undang-undang ini, pemerintah melalui badan BPJPH ingin memberikan jaminan dan perlindungan kepada konsumen muslim untuk mendapatkan informasi terkait kehalalan produk. Tidak hanya itu dalam Undang-undang dijelaskan kewajiban bersertifikasi juga dapat berpengaruh dalam meningkatakan nilai jual dan daya saing pasar di 
tengah trend global untuk mengkonsumsi produk halal baik di wilayah muslim maupun non muslim.

Kabupaten Bangkalan merupakan salah satu Kabupaten di daerah Madura dengan penduduk mayoritas Muslim. Total penduduk di Bangkalan dalam data pusat statistik tercatat terdapat 970.894 jiwa. Hampir 98 persen adalah beragama Islam. Berdasarkan data potensi industri di Kabupaten bangkalan tahun 2018 yang diperoleh dari Dinas koperasi dan UKM provinsi Jawa Timur, diperoleh seperti tampak dalam tabel 1 . Tidak kurang dari 166.768 unit usaha mikro kecil dan menengah terdapat di Bangkalan dengan menyerap tenaga kerja kurang lebih 210.003 orang.

Tabel 1. Ringkasan Data Potensi UMKM Bangkalan tahun 2018

\begin{tabular}{|c|c|c|c|c|c|}
\hline \multirow{2}{*}{ No } & \multirow{2}{*}{ Kelas Komoditas } & \multicolumn{2}{|c|}{ Unit Usaha } & \multicolumn{2}{c|}{ Tenaga Kerja } \\
\cline { 3 - 6 } & & unit & $\%$ & orang & $\%$ \\
\hline 1 & Pertanian & 131.112 & 79 & 145.761 & 69.4 \\
\hline 2 & Pertambangan dan penggalian & 293 & 0.2 & 303 & 0.14 \\
\hline 3 & Industri pengolahan & 5.712 & 3.4 & 13.600 & \\
\hline 4 & Listrik, gas dan air & 0 & 0 & 0 & 0 \\
\hline 5 & Konstruksi & 29 & 0.01 & 149 & 6.5 \\
\hline 6 & Perdagangan hotel dan & 22.390 & 13.4 & 38.573 & 18.4 \\
\hline 7 & restoran & & & & \\
\hline 8 & Transportasi & 3.057 & 1.9 & 3.882 & 2 \\
\hline 9 & Keuangan & 37 & 0.02 & 152 & 0.8 \\
\hline \multicolumn{2}{|c|}{ Jasa-jasa } & 4.138 & 2.5 & 7.583 & 4 \\
\hline
\end{tabular}

Sumber: Dinas Koperasi dan UKM Jatim

Dari potret potensi industri mikro, kecil dan menengah Kabupaten Bangkalan tersebut tampak pertanian, resto dan pengolahan pangan memiliki peran strategis dalam perekonomian masyarakat. Ketiga komoditas tersebut bersentuhan erat dengan produk makanan dan minuman yang notabene harus dijamin hak informasi kehalalan dan keharamannya. Selama ini kesadaran atas konsumsi produk halal belum tertanam kuat di tengah-tengah masyarakat, baik dari kalangan produsen, penjual ataupun konsumen. Namun ghiroh (gairah) keislaman akan sangat terasa dalam kehidupan bermasyarakat dan akan tampak reaktif bila berkaitan isu tentang daging babi atau tikus atau daging ayam yang tidak dipotong secara halal dalam produk makanan yang dijual.

Kecamatan Tragah memiliki sedikitnya 10
UMKM aktif yang bergerak dibidang pangan olahan. Dari kesepuluh UMKM tersebut hanya satu produk yang telah mendapatkan sertifikat halal. Beberapa produk lainnya beredar di masyarakat sekitar tanpa ada label halal maupun diberikan label halal tanpa adanya legalisasi. Kondisi tersebut menyiratkan bahwa masyarakat masih belum memiliki pemahaman dan kesadaran yang kuat akan jaminan produk halal. Kesadaran akan mengkonsumsi produk halal perlu ditingkatkan di tengah masyarakat Kec. Tragah Bangkalan, baik dari kalangan produsen, penjual ataupun konsumen, agar terwujud tatanan masyarakat muslim yang sesuai syariat Islam.

\section{METODE}

Untuk mengatasi persoalan yang dihadapi oleh pelaku UMKM di Kecamatan Tragah, digunakan metode yang diuraikan dalam beberapa tahapan yang meliputi Focus Group Discussion (FGD), pelatihan, dan pendampingan. Secara rinci, metode pelaksanaan yang digunakan adalah sebagai berikut :

\section{Focus Group Discussion (FGD)}

Tahap Focus Group Discussion (FGD) diawali dengan survey lapangan dan mendata jumlah pelaku UMKM aktif dan tingkat pemahaman mayarakat terkait produk dan sertifikasi halal serta pemetaan terhadap permasalahan yang dihadapi masyarakat terkait produk dan sertifikasi halal.

\section{Pelatihan}

Tahap pelatihan pemahaman produk halal dan sertifikasi halal untuk kalangan Produsen dan penjual dilaksanakan dengan metode ceramah dengan teknik presentasi dengan materi diantaranya :

a. Produk halalan Thoyyiban dalam perspektif Islam.

b. Pemahaman kebersihan dan Kenajisan dalam perspektif Islam.

c. Ragam Putusan Fatwa MUI berkaitan dengan produk halal.

d. UU No. 33 tahun 2014 tentang Sistem Jaminan Halal (SJH).

e. Prosedur pengajuan Nomor Sertifikat PIRT (Pangan Industri Rumah Tangga).

f. Prosedur pengajuan Sertifikasi Halal LPPOM MUI melalui form Cerol SS23000

\section{Pendampingan}

Tahapan pendampingan dilaksanakan melalui kegiatan pembuatan label produk yang menarik memenuhi ketentungan pendampingan 
pendaftaran No. PIRT melalui Dinas Kesehatan dan pendampingan pengisian form pendaftaran sertifikasi halal online Cerol SS23000 pada web https://e-lppommui.org/.

\section{HASIL DAN PEMBAHASAN}

\section{Hasil Focus Group Discussion (FGD)}

Pelaku usaha mikro kecil dan menengah di Kecamatan Tragah pada awalnya merasa bahwa hasil pertaniaan saat sedang panen sangat melimpah ruah. Diantanya jagung, kacang hijau, dan singkong. Setelah diadakan pelatihan dari Dinas Perindustrian dan Ketenagakerjaan, maka beberapa pelaku usaha menindaklanjuti hasil pelatihan tersebut hingga mampu membuat produk yang dapat diterima pasar. Beberapa produk pangan olahan yang dihasilkan diantaranya adalah: tempe, kue, keripik singkong, kerupuk puli, dan bahkan ada produk dari desa Soket Dajah yang sudah memiliki No PIRT yaitu Tatochis (Tragah Tortila Chips). Sayangnya tidak semua pelaku usaha melakukan hal yang sama. Beberapa pelaku UMKM cukup puas hanya dengan membuat produk dan dijual dengan kemasan dan pasar 'seadanya'. Banyak dari produk pangan tersebut yang kiranya dapat menjaring pasar yang lebih luas jika ditingkatkan segi pengemasan dan pelabelan.

Pelaku UMKM hanya menjual produknya menggunakan pengemas plastik sederhana dan menjualnya di rumah maupun ke warung-warung kecil yang ada di sekitar kediaman pengusaha. Pengusaha melakukan proses produksi dan pemasaran secara konvensional karena keterbatasan ilmu pengetahuan dan kemampuan memakses informasi. Pengusaha mengungkapkan bahwa pelanggan tetap puas dengan produk yang dihasilkan walaupun tidak terdapat label halal karena selama bertetangga masyarakat mengganggap bahwa pengusaha pasti memproduksi produknya menggunakan barang halal dan mengolahnya dengan cara yang baik.

Kegiatan pengabdian ini dilaksanakan dalam rangka meningkatkan kesadaran dan pemahaman masyarakat khususnya UMKM akan produk halal dan sertifikasi halal, meningkatkan jumlah produsen dari UMKM Tragah Bangkalan yang berkeinginan untuk mengajukan Sertifikasi Halal atas produk yang dihasilkan, serta meningkatkan peran dan partisipasi masyarakat dalam pengawasan produk makanan dan minuman yang halal

\section{Pelatihan Pelaku UMKM tentang Produk Halal dan Sertifikasi Halal}

Salah satu upaya pemberdayaan dalam pengabdian ini adalah dengan meningkatkan kemampuan masyarakat melalui pelatihan dan pendampingan. Pelatihan berfungsi untuk menanamkan pengetahuan dan pendampingan berfungsi sebagai proses praktis untuk mencapai tujuan kegiatan secara maksimal. Tenaga pendamping dari Tim Abdimas berfungsi sebagai fasilitator, komunikator, motivator dan dinamisator. Selain diarahkan untuk memfasilitasi proses pengambilan keputusan yang terkait dengan kebutuhan masyarakat, para pendamping mengembangkan perencanaan dan pelaksanaan kegiatan secara partisipatif. Pelatihan awal dimulai dengan memberikan penyuluhan dan pendampingan mengenai pengemasan produk dan pembuatan label. Beberapa produk yang sudah dimiliki produsen diberikan label dan dikemas dengan plastik kemasan siap pakai sehingga produk yang dihasilkan memiliki nilai jual yang lebih tinggi. Selain daripada itu, pemberian label yang lengkap juga bagian dari proses pemenuhan hak konsumen untuk mendapatkan informasi yang benar jelas dan jujur dari produk yang akan dikonsumsi. Label tersebut berisi antara lain : nama produk, merek, produsen, alamat produsen, komposisi, berat bersih, dan tanggal kadaluarsa. Label ini menjadi penting karena nantinya akan menjadi syarat awal yang harus dimiliki saat mendaftarkan Nomor Pangan Industri Rumah Tangga (PIRT).

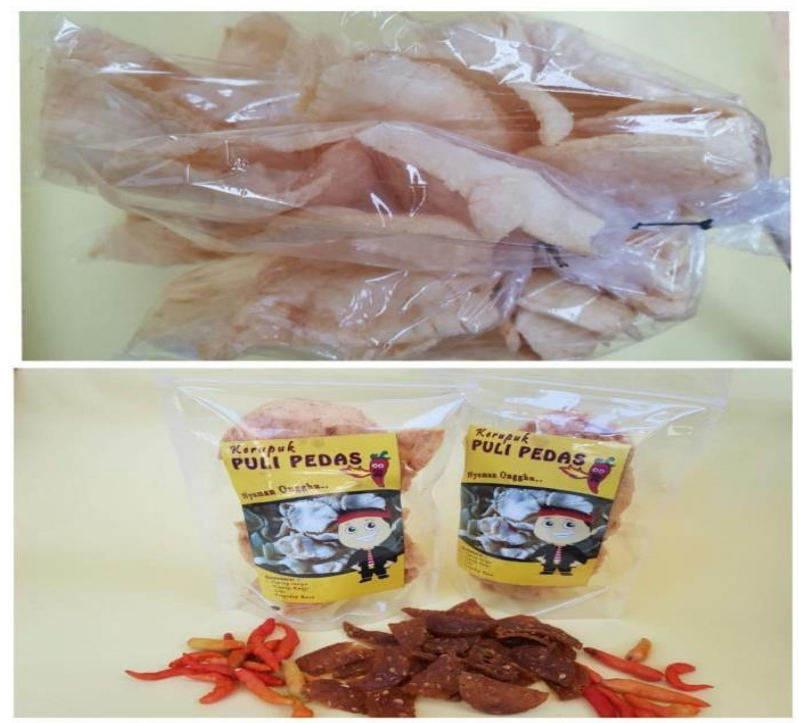

Gambar 1. Kemasan Krupuk Puli Lama dan Baru 


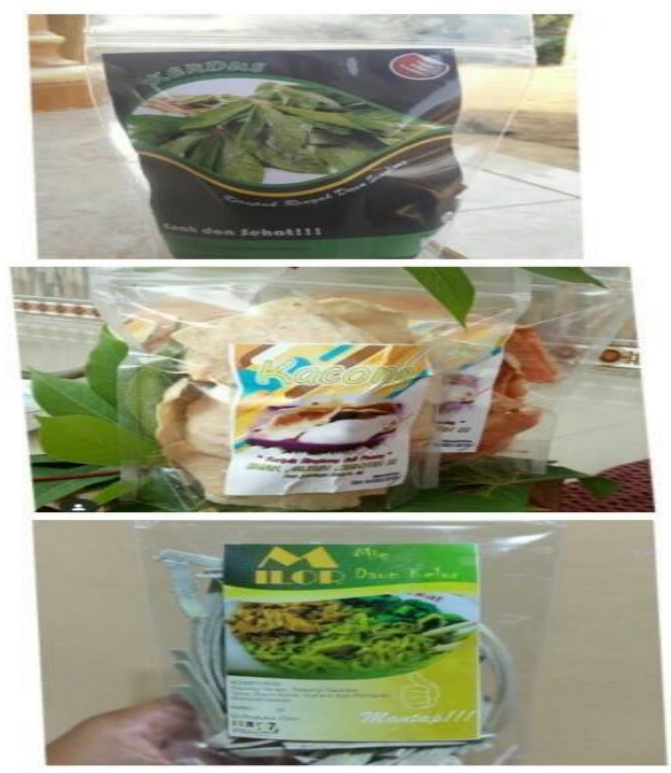

Gambar 2. Beberapa Produk Olahan Desa Tragah

Penyuluhan diberikan kepada pelaku UMKM mengenai pengetahuan tentang produk halal dan hak konsumen dalam mengkonsumsi produk. Hal ini penting mengingat masyarakat terkadang tidak memperhatikan apakah produk yang mereka konsumsi ini halal atau tidak (haram). Para pengusaha cenderung tak acuh terhadap kehalalan produk yang mereka produksi, mereka beranggapan bahwa produk yangmereka ciptakan ini terbuat dari bahanbahan aman. Padahal aman saja tidak cukup, karena meskipun dibuat dari bahan yang aman belum tentu produk tersebut dikatakan halal. Kriteria halal terbagi 2, yaitu berdasarkan proses dan halal berdasarkan substansi. Halal berdasarkan proses, yaitu untuk pangan yang berasal dari tumbuhan dan ikan pada waktu proses pengolahan, penyimpanan, transportasi serta alat yang dipakai tidak habis digunakan untuk babi dan bahan tambahannya halal sedangkan untuk bahan pangan yang berasal dari tumbuhan dan disembelih menyebut nama Allah. Halal berdasarkan substansi yakni : (1) tidak mengandung daging babi, atau binatang yang dilarang oleh ajaran Islam untuk memakannya; (2) semua bentuk minuman yang tidak mengandung alcohol.

Pendampingan proses pengajuan sertifikasi halal LPPOM MUI dilaksanakan secara praktis oleh tim dengan kegiatan diantaranya :

\section{a. Mempersiapkan dan melengkapi persyaratan pengajuan sertifikasi halal}

Salah satu syarat pokok pengajuan sertifikasi halal adalah memiliki Nomor Sertifikat Pangan Industri Rumah Tangga (PIRT). Nomor PIRT diajukan melalui Dinas Kesehatan daerah. Sebelum mendapatkan nomor PIRT, Pengusaha wajib mengikuti penyuluhan kemanan pangan yang diadakan oleh Dinas Kesehatan sesuai dengan kuota yang telah ditetapkan. Pengusaha cukup mendatangi Dinas Kesehatan dengan membawa fotocopy KTP, pas foto $3 \times 4$ dua buah, denah lokasi usaha, stempel/logo usaha, draft label produk, dan mengisi formulir yang telah disediakan. Pengusaha akan dihubungi oleh Dinas Kesehatan terkait tanggal pelaksanaan penyuluhan keamanan pangan. Setelah mengikuti penyuluhan, puskesmas akan mengunjungi tempat usaha yang bersangkutan untuk ditilik mengenai keamanan dan kebersihan tempat produksi. Apabila dianggap sudah memenuhi standar penilaian, maka akan diterbitkan sertifikat keikutsertaan penyuluhan keamanan pangan dan sertifikat nomor pangan industri rumah tangga.
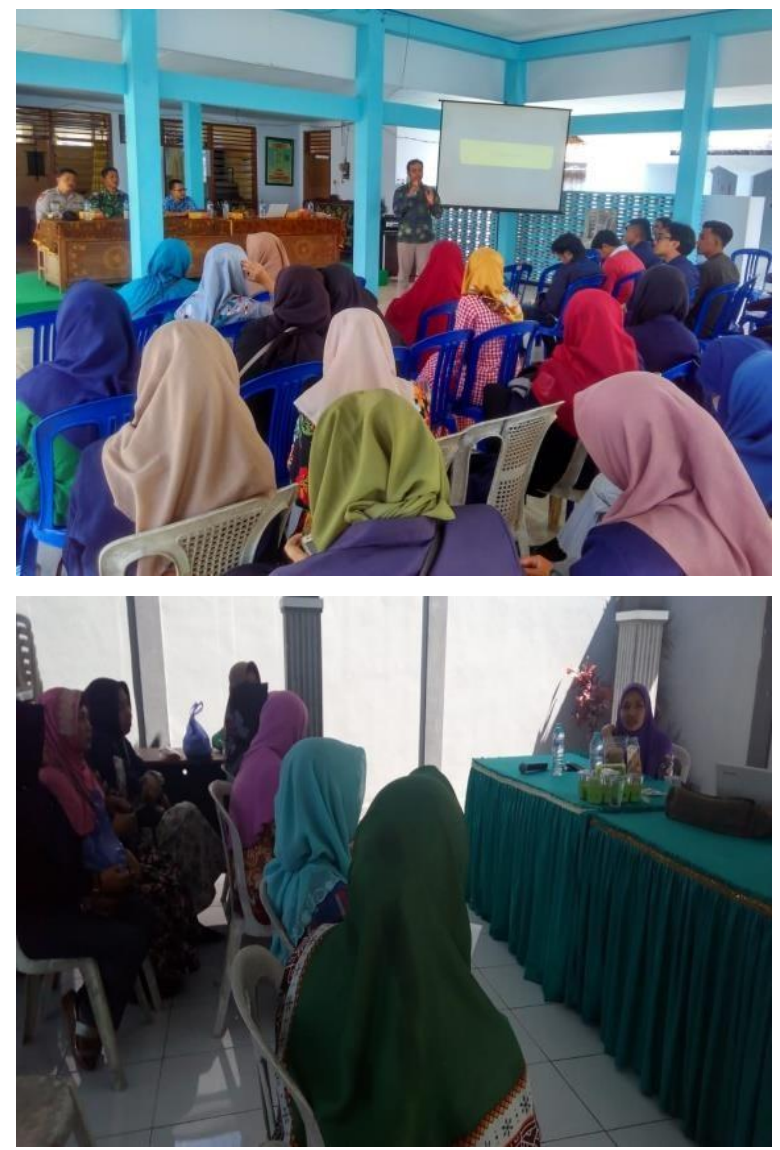

Gambar 3. Penyuluhan Produk Halal 


\section{b. Pendampingan (coaching) pengisian form sertifikasi halal}

Pengajuan sertifikasi halal sudah dapat dilaksanakan online melalui https://elppommui.org/. Sebelum melakukan pendaftaran online, pengusaha harus mengikuti pelatihan Sistem Jaminan Halal yang diadakan LPPOM MUI, baik berupa pelatihan reguler maupun pelatihan online (e-training). Pengusaha juga harus menyiapkan dokumen yang diperlukan untuk sertifikasi halal, antara lain: daftar produk, daftar bahan dan dokumen bahan, daftar penyembelih (khusus RPH), matriks produk, Manual SJH, diagram alir proses, daftar alamat fasilitas produksi, bukti sosialisasi kebijakan halal, bukti pelatihan internal dan bukti audit internal.

Setelah mempersiapkan dan melengkapi seluruh dokumen, pengusaha dapat melakukan pendaftaran sertifikasi halal secara online di sistem Cerol melalui website www.elppommui.org. CEROL-SS23000 adalah sistem pelayanan sertifikasi halal LPPOM MUI secara online. Dengan sistem ini perusahaan dapat mengajukan permohonan sertifikasi halal produk secara online tanpa batas waktu dan tempat. Harapannya, dengan dibuat secara online, pelayanan sertifikasi halal akan bisa lebih cepat dan lebih baik.

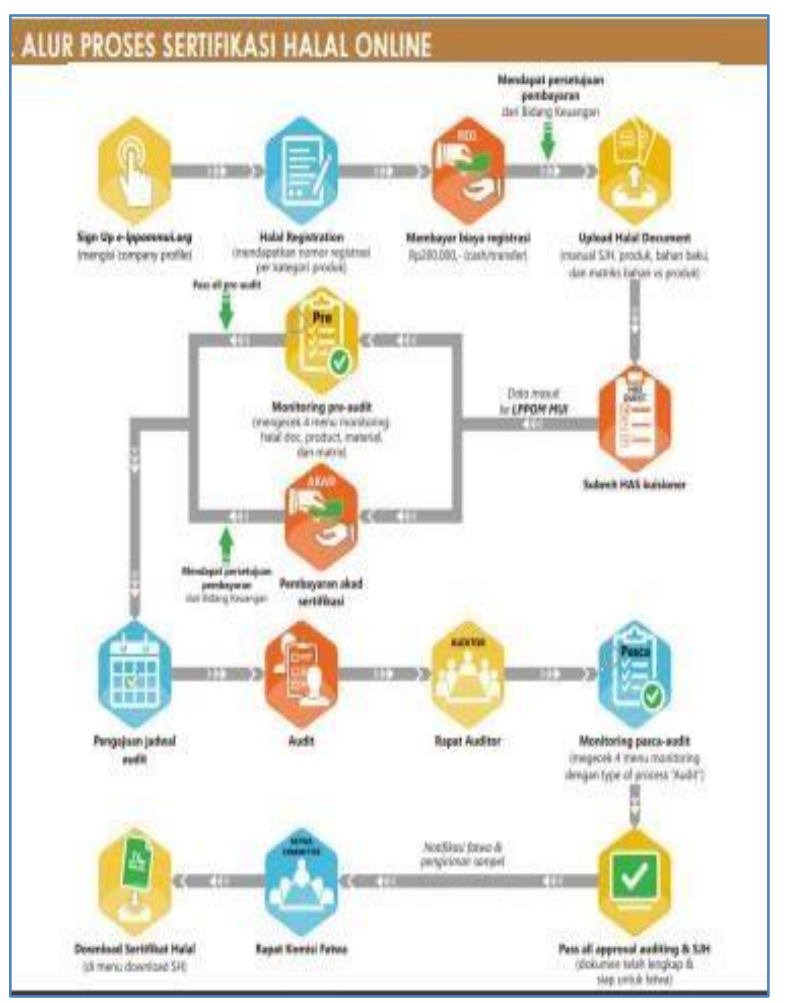

Gambar 4. Alur Sertifikasi Halal On-Line
LPPOM MUI mengklaim bahwa CEROLSS23000 memiliki keunggulan sebagai berikut: 1) Total waktu proses sertifikasi menjadi lebih cepat; 2) Dapat memonitor perkembangan proses sertifikasi secara real time; 3) Dapat digunakan untuk registrasi pengembangan fasilitas (outlet/dapur/gudang); 4) Mengurangi penggunaan kertas (Go Green); 5) Dapat mengunduh Sertifikat Halal dari sistem data sertifikasi tersimpan di sistem dengan baik (History); 6) Tidak ada batas watu dalam pengisian data, sehingga dapat dikerjakan secara bertahap (dicicil); 7) Kemudahan akses pencarian produk bersertifikat halal.

Selain sertifikasi halal, CEROL-SS23000 juga dapat melayani : 1) Pengajuan approval bahan jika terdapat penggantian bahan selama masa berlakunya Sertifikat halal; 2) Pengiriman laporan berkala sebagai bentuk komitmen untuk menjaga kehalalan produk; 3) Pencarian nomor sertifikat halal dari produk yang telah disertifikasi, produk yang telah disertifikasi dan perusahaan yang sudah mengajukan sertifikasi.

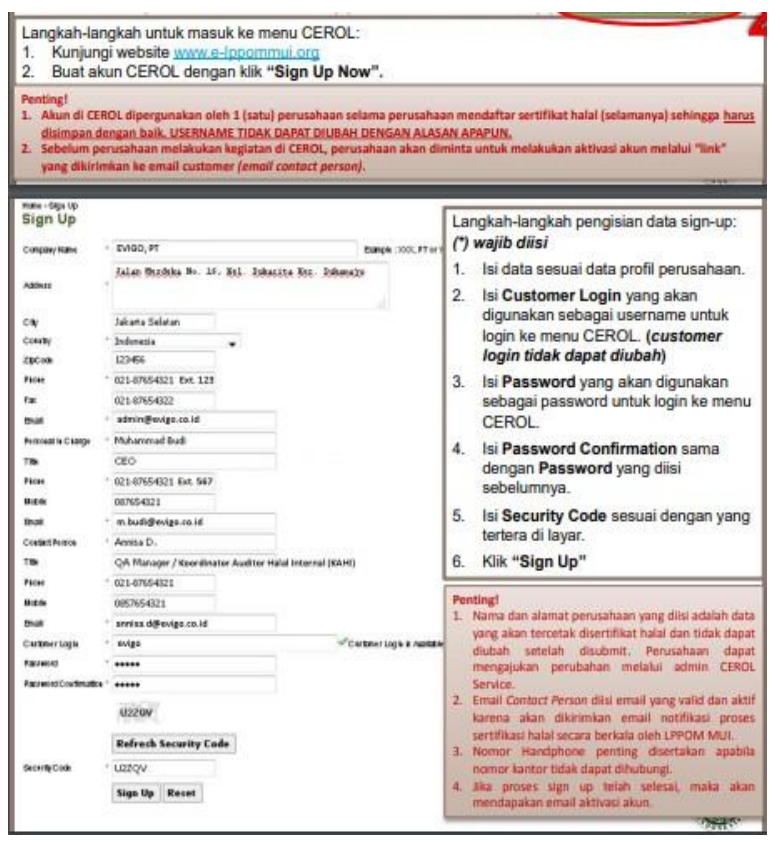

Gambar 5. Dokumen Manual Cerol SS23000

Pendampingan proses pengisian pendaftaran sertifikasi halal dengan sistem Cerol SS23000 melalui online terkendala dengan keterbatasan penggunaan teknologi dan akses internet yang kurang memadai. Kendala lain adalah pemenuhan dokumen prasyarat pendaftaran sertifikasi halal yang sebagian besar tidak dapat dipenuhi dalam waktu singkat. Pendampingan diberikan pada proses pendaftaran akun Cerol dan prosedur pengisian Cerol online. 


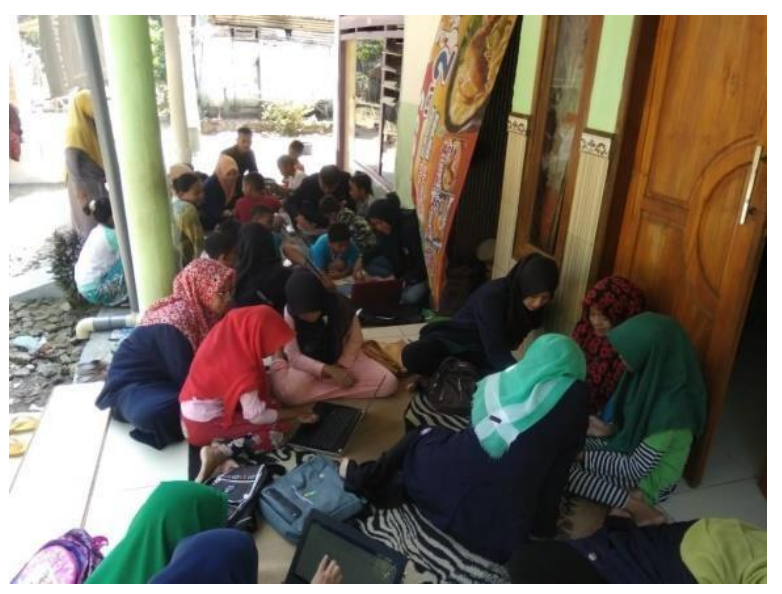

Gambar 6. Pendampingan Pengisian Formulir Pendaftaran dalam Akun Cerol

Pemerintah Provinsi Jawa Timur melalui Dinas Koperasi dan UKM Provinsi Jatim menyediakan anggaran $\mathrm{Rp} 60$ milliar setiap tahun guna memberikan pelatihan, pendampingam vokasional, promosi dan pengurusan sertifikasi halal. Hal ini untuk menindaklanjuti banyaknya pelaku UKM di sektor makanan dan minuman yang masih kesulitan mendapatkan sertifikasi halal. Selain daripada itu, Dinas Perindustrian dan Perdagangan serta Bank Indonesia juga memberikan fasilitas bantuan pendaftaran sertifikasi halal yang pada 2018 diberikan kepada 100 UMKM pada agenda Indonesia Shari'a Economic Festival (ISEF) 2018.

\section{KESIMPULAN}

Pelaku UMKM di Kecamatan Tragah berpotensi meningkatkan perekonomian daerah dengan menjual produk yang berdaya saing. Dari sekian banyak UMKM bidang pangan, hanya satu UMKM yang terdata telah memiliki nomor PIRT sebagai prasyarat pendaftaran sertifikasi halal. Pelatihan dan pendampingan pendaftaran sertifikasi halal online ini membantu pelaku usaha untuk dapat mendaftarkan produknya sehingga mendapatkan sertifikasi halal dari LPPOM MUI. Pendampingan pendaftaran sertifikasi halal terkendala pada pemenuhan dokumen prasyarat yang memakan waktu lama dan keterbatasan penggunaan teknologi. Sejauh ini, Untuk mendukung semangat Undang-Undang Jaminan Produk Halal, Pemerintah daerah seharusnya ikut serta dalam memfasilitasi UMKM untuk mendapatkan kemudahan pendaftaran sertifikasi halal melalui pendaftaran kolektif maupun bantuan pendanaan karena dengan sertifikasi halal yang dimiliki, diharapkan dapat meningkatkan nilai jual produk UMKM Kecamatan Tragah sehingga dapat membantu meningkatkan perekonomian daerah.

\section{DAFTAR PUSTAKA}

Indonesia (MUI). 2019. Prosedur Sertifikasi Halal. Diakses dari laman resmi www.halalmui.org. tanggal 20 Juli 2019
---------2019. Persyaratan Halal MUI (HAS23000) (SJH)

Rezfi, D. 2016. Pelaksanaan Sertifikasi Halal Terhadap Restoran dan Rumah Makan Dikaitkan dengan Perlindungan Konsumen. Skripsi. Universitas Andalas, Padang.

Wahyuni, E \& Rohmah, S. 2016. Pentingnya Sertifikasi Halal Terhadap Pemasaran Produk. Universitas Islam Indonesia, Yogyakarta. 